\title{
Trade Potential Analysis between China and Europe under "the Belt and Road" Initiative
}

\author{
Pei-Zhi WANG ${ }^{1}$, Yu-Han ZHENG ${ }^{2, b}$ and Li-Ping SUN ${ }^{3}$ \\ ${ }^{1,2,3}$ Shandong University of Finance and Economics, Jinan, China \\ awpzmail@126.com, b andy19940119@163.com, csunliping1999@126.com
}

Keywords: Comparative advantage, Trade Complementarity, Gravity model, Trade potential.

\begin{abstract}
Recently, the European market has become an indispensable part of Chinese foreign trade. In 2013, China put forward "the Belt and Road" initiative in order to communicate the Eurasian Continent. There has been 24 European countries joining in "the Belt and Road" initiative while most developed countries of the EU still stayed on the sidelines. This paper selects the data of total export-import volume between China and some European trade partners from 2007 to 2016 and divides these countries into two control groups that one group has been in "the Belt and Road" initiative and another not. I use RCA to explore our own comparative advantages. On that basis, the paper is aimed at seeking new trade potential between China and Europe by creating new Gravity Model so that we can look forward to the trend of "the Belt and Road" initiative to Europe in the future. After empirical analysis, we can see that China has many comparative advantages and new trade potentials were created under "the Belt and Road" initiative so that we need to develop complementary based on our own advantages and make full use of the B\&R initiative to find further trade potentials with Europe. Former researches were mainly about China-EU's trade relations and situations and this paper focuses on the trade potential between China and Europe under "the Belt and Road” initiative.
\end{abstract}

\section{Introduction}

Since the ancient Silk Road till now, trade between China and Europe has been constantly expanding. In 2016, China's total import and export to Europe reached 5.980 billion U.S. dollars, accounting for $16.22 \%$ of China's total import and export volume. It is the second largest continent for import and export of China. In 2013, China put forward "the Belt and Road" initiative, linking more than 60 countries in the world and more than 60 countries include many European countries. With the formation of a China-centered trading bloc in the countries along the B\&R initiative and a tremendous impact on the trade of the European Union and even of Europe as a whole, the benefits of the "Belt and Road" strategy are not just the elimination of trade barriers. The EU itself has remained neutral as the destination of the B\&R initiative. China is also trying hard to bring the rest of Europe into the process of discussing, sharing, building together and winning together in the B\&R initiative.

Based on the comparative advantage of China itself, this paper selects the major developed countries in Europe that have not joined in the B\&R initiative to study the trade complementarities and uses the gravity model to explore the trade potential between China and Europe of the B\&R initiative in the future. We hope that we can truly realize the great ideal of mutual benefit and common development.

\section{Literature Review}

The development of China's import and export trade is getting faster and faster, and the trade potential between China and other countries has drawn much attention. Gravity model, as an important choice applied to bilateral trade, has been favored by many scholars. Huai-Yu TAN (2015) conducted an analysis of trade closeness and complementarity and used gravity model to make empirical analysis of 1999-2014 China-EU bilateral trade data to explore the potential of China-EU trade. He found that the trade tightness between China and the EU shows a downward trend. Recent years, many scholars 
in China have paid great attention to the research on the trade between China and Europe. Chun-Rong YAN analyzed the trade complementarities between China and the EU and China's trade competitiveness with the EU through the trade intensity index and export similarity index respectively in 2010. In 2011 she analyzed the product comparative advantages of China and the EU's seven major member states, using the Revealed Comparative Advantage Index. It can be seen that most scholars in China study the trade relations and situations between China and EU countries. No one has done any research on the potential of China's trade with Europe under the B\&R initiative.

\section{China-EU Trade Status Quo}

RCA is used to measure whether a country has comparative advantage over other countries in a certain industry or not. We can analyze the development and change of an industry in world import and export through the dominant comparative advantage index of different years. RCA was first proposed by Balassza in 1965 to measure the size of the country's comparative advantage in this industry. The formula for RCA is:

$$
R C A_{i j}=\frac{x_{i j} / x_{i}}{x_{w i j} / x_{w}}
$$

Among them, $R C A_{i j}$ represents the RCA of products $\mathrm{j}$ in country $\mathrm{i}$; $\mathrm{X}_{\mathrm{ij}}$ represents the exports of products $\mathrm{j}$ in country $\mathrm{i}$ this year; $\mathrm{X}_{\mathrm{i}}$ represents the total exports of country $\mathrm{i}$ in this year; $\mathrm{X}_{\mathrm{wj}}$ represents the sum of the exports of products $\mathrm{j}$ in this year all over the world; $\mathrm{X}_{\mathrm{w}}$ represents the total exports of the world. In this paper, we use the RCA of Japan International Trade Association to set the standard of export competitiveness. When $0<\mathrm{RCA}<1$, country i has a comparative disadvantage in the current year's exports of products $\mathrm{j}$. The more its value deviates from 1 to 0 , the more obvious the comparative disadvantage is; RCA $>1$ indicates that country i has a comparative advantage in the current year's exports of products $\mathrm{j}$. The larger the value, the more obvious the comparative advantage is displayed. If RCA $>2.5$, particularly, then there is a strong competitive advantage; if $\mathrm{RCA}<0.8$, the more disadvantaged than the more prominent.

Choosing the data from UNCTAD database, we classify the products into categories 0-9 in accordance with the one-digit index of the REIT for International Trade Classification (SITC).

Table1 2007-2016 China’s RCA of Ten Products

\begin{tabular}{|l|l|l|l|l|l|l|l|l|l|l|}
\hline Year & 2007 & 2008 & 2009 & 2010 & 2011 & 2012 & 2013 & 2014 & 2015 & 2016 \\
\hline Catergory 0 & 0.5131 & 0.4206 & 0.4343 & 0.4554 & 0.4600 & 0.4376 & 0.4252 & 0.4104 & 0.4043 & 0.4478 \\
\hline Catergory 1 & 0.1409 & 0.1349 & 0.1519 & 0.1548 & 0.1587 & 0.16 & 0.1473 & 0.1529 & 0.1732 & 0.1925 \\
\hline Catergory 2 & 0.2312 & 0.2284 & 0.199 & 0.1793 & 0.1799 & 0.1708 & 0.1673 & 0.181 & 0.1773 & 0.1803 \\
\hline Catergory 3 & 0.1722 & 0.1626 & 0.1463 & 0.1272 & 0.1063 & 0.0976 & 0.096 & 0.0987 & 0.1232 & 0.1496 \\
\hline Catergory 4 & 0.0986 & 0.117 & 0.0663 & 0.0456 & 0.0478 & 0.0472 & 0.0535 & 0.0556 & 0.058 & 0.0534 \\
\hline Catergory 5 & 0.4313 & 0.5081 & 0.433 & 0.489 & 0.5483 & 0.5151 & 0.5069 & 0.5296 & 0.5078 & 0.5085 \\
\hline Catergory 6 & 1.2322 & 1.3221 & 1.2024 & 1.2124 & 1.2844 & 1.3038 & 1.3351 & 1.3718 & 1.3652 & 1.3606 \\
\hline Catergory 7 & 1.2072 & 1.3051 & 1.3903 & 1.4056 & 1.4386 & 1.4204 & 1.4309 & 1.3487 & 1.2774 & 1.2545 \\
\hline Catergory 8 & 2.1452 & 2.1694 & 2.0743 & 2.1183 & 2.234 & 2.3227 & 2.3283 & 2.251 & 2.0172 & 2.0058 \\
\hline Catergory 9 & 0.0428 & 0.0258 & 0.0252 & 0.0196 & 0.0273 & 0.0124 & 0.0135 & 0.0196 & 0.018 & 0.0435 \\
\hline
\end{tabular}

It can be seen from Table 1 that, as for product category, our country has always had comparative advantages in category 6(finished products by material), 7(mechanical and transportation equipment) and 8(miscellaneous finished products), while category 8 even have a strong comparative advantage close to 2.5. China's labor resources are very rich while capital, technology and natural resources endowment are relatively weak, so the past 10 years, China's exports were mainly labor-intensive products. Category 1 to 4 and 9 products, RCA is very low, showing more prominent comparative 
disadvantage. Secondly, from the year of view, with the development of science and technology, we firmly sought the position of labor-intensive products in the world while actively pursuing capital and technological endowments to make the comparative advantage of capital-technology-intensive products gradually rise. It can be foreseen that in the coming years, we should increase exports of labor-intensive products to countries with scarce labor resources and still need to strengthen trade with countries with abundant capital and technological endowments to meet the needs of domestic production. Undoubtedly, the trade links with Europe will not only keep the export of labor-intensive products of our country at a high level, but also the capital-intensive products of the developed countries in Europe which are also indispensable to China's import in recent years.

\section{Empirical Analysis of the Impact of China-Europe Trade}

\section{Theoretical Model and Variable Settings}

This section chooses the gravity model of Anderson and Van Wincoop as the basis, adds the annual GDP level of the exporting and importing countries, whether the two countries sign the relevant trade agreements and other variables to construct a new gravity model:

$$
\operatorname{LnTEI_{ijt}}=\beta_{0}+\beta_{1} \operatorname{LnGDP_{it}}+\beta_{2} \operatorname{LnGDP_{jt}}+\beta_{3} \operatorname{LnDist}_{i j}+\beta_{4} B R+\beta_{5} \text { Fcri }+\beta_{6} \text { Deva }+\mu_{i j}
$$

$\operatorname{Ln} T E I_{i j}$ represents the natural logarithm of the total import and export volume between China and country $\mathrm{j}$ in year $\mathrm{t} ; \beta_{0}$ is a constant term; $L n G D P_{i t}$ represents the natural logarithm of China's GDP in year $\mathrm{t}$; $\operatorname{LnGDP_{jt}}$ represents the natural logarithm of the GDP of country $\mathrm{j}$ in year $\mathrm{t}$; LnDist $_{i j}$ represents the logarithm of the distance between China and country j. $B R$ is a dummy variable, which indicates whether country $\mathrm{j}$ joins "the Belt and Road" initiative or not while the assignment of joining is 1 and the rest is 0 . F cri is the dummy variable whether affected by the 2008 financial crisis. The affected year had a value of 1 and the rest had a value of 0 . Deva said that in 2015 the downturn in the euro area currency devaluation of the virtual variables affected countries in the corresponding year had a value of 1 and the rest is $0 . \beta_{1}-\beta_{6}$ represents the regression coefficient, $\mu_{i j}$ is the standard random error.

\section{Sample Selection and Data Source}

A total of 27 countries from 2007 to 2016 in Europe were selected as the samples, including 17 Central and Eastern European trading partners (Russia, Poland, Czech Republic, Slovakia, Hungary, Slovenia, Croatia, Romania, Bulgaria, Serbia Montenegro, the Republic of Macedonia, Bosnia and Herzegovina, Albania, Estonia, Lithuania and Latvia), as well as the 10 major European countries that have not yet established free trade area cooperation with China and whose import and export volume with China accounts for more than half of Europe (Belgium, the United Kingdom, Germany, France Italy, the Netherlands, Spain, Sweden, Finland and Ireland) to analyze the trade potential of China and the developed countries in Europe that have not yet joined "the Belt and Road" initiative, in anticipation of the future development direction and strategy of China's the B\&R initiative in Europe. The total volume of import and export trade between China and the above countries comes from China Statistical Yearbook. The GDP of all countries comes from the World Bank database. The distance between China and other countries is taken from the Google calculation software.

\section{Empirical Result Analysis}

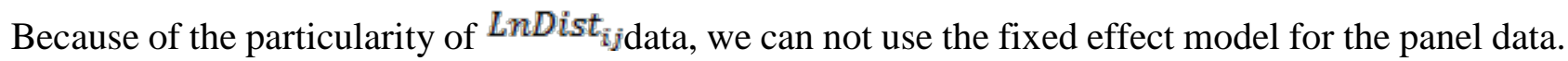
Therefore, this paper chooses Stata software to use the random effect model to regress the constructed gravitational model. As shown in Table 2, the stochastic effect model regression of the total variables and the single dummy variables respectively was conducted. Most of the explanatory variables are in line with the $1 \%$ significance level test, and the symbols of the variables are also in line with expectations. 
Table2 Empirical Results of the Bilateral Trade Gravity Model between China and European Countries

\begin{tabular}{|l|l|l|l|l|}
\hline & $(1)$ & $(2)$ & $(3)$ & $(4)$ \\
\hline VARIABLES & $\operatorname{lnTEI}$ & $\operatorname{lnTEI}$ & $\operatorname{lnTEI}$ & $\operatorname{lnTEI}$ \\
\hline & & & & \\
\hline $\operatorname{lnGDPi}$ & $0.507^{* * *}$ & $0.519^{* * *}$ & $0.518^{* * *}$ & $0.610^{* * *}$ \\
\hline & $(0.0572)$ & $(0.0628)$ & $(0.0515)$ & $(0.0509)$ \\
\hline $\ln \mathrm{GPj}$ & $0.992^{* * *}$ & $1.040^{* * *}$ & $1.007^{* * *}$ & $1.016^{* * *}$ \\
\hline & $(0.0557)$ & $(0.0523)$ & $(0.0525)$ & $(0.0513)$ \\
\hline $\ln$ Dist & $-1.280^{* *}$ & $-1.464^{* *}$ & $-1.401^{* *}$ & $-1.438^{* *}$ \\
\hline & $(0.575)$ & $(0.609)$ & $(0.576)$ & $(0.587)$ \\
\hline BR & $0.111^{*}$ & $0.0980^{*}$ & & \\
\hline & $(0.0567)$ & $(0.0594)$ & & \\
\hline Fcri & $-0.215^{* * *}$ & & $-0.215^{* * *}$ & \\
\hline & $(0.0333)$ & & $(0.0331)$ & \\
\hline Deva & $-0.120^{* * *}$ & & & $-0.103^{* *}$ \\
\hline & $(0.0404)$ & & & $(0.0402)$ \\
\hline Constant & $-16.18^{* * *}$ & $-16.19^{* * *}$ & $-15.82^{* * *}$ & $-18.46^{* * *}$ \\
\hline & $(4.945)$ & $(5.065)$ & $(4.734)$ & $(4.794)$ \\
\hline & & & & \\
\hline Observations & 269 & 269 & 269 & 269 \\
\hline Number of id & 27 & 27 & 27 & 27 \\
\hline
\end{tabular}

Robust standard errors in parentheses $* * * \mathrm{p}<0.01,{ }^{*} \mathrm{p}<0.05,{ }^{*} \mathrm{p}<0.1$

The coefficient of $L n G D P_{i t}$ is positive, on behalf of China's GDP growth can promote China's trade partners and import and export trade. The coefficient of $L n G D P_{j t}$ is positive, representing the greater the trade partner's GDP, China's total import and export trade with its larger, the closer the trade relations. Obviously, $0.992 \%>0.507 \%$, so for Europe, the impact of trading partner country GDP is greater than the impact of China's GDP.

The coefficient of $\operatorname{LnGDP_{\text {it}}}$ is negative, on behalf of the longer the distance between the two countries, the higher the cost of transportation. The coefficient is -1.280 , which is an important factor that can not be ignored in trade relations.

The coefficient of $B R$ shows that participating in "the Belt and Road" Initiative has a catalytic effect on the trade relations between China and its trading partners. the $B \& R$ initiative has just come into shape and infrastructure construction has not yet been completed. This effectiveness can be achieved in a short period of time and people are very much looking forward to the extent to which their future can be developed.

The Fcri and Deva respectively indicate the impact of the 2008 financial crisis and the drastic devaluation of the euro area in 2014 on the total volume of imports and exports between China and the European trading partners, which shows a negative correlation at the $1 \%$ significance level, that is, the financial crisis and the sharp devaluation of the currencies of partner countries can have a negative effect on bilateral trade.

\section{Estimation of Trade Potential between China and European Countries}

The estimation of trade potential value is an important part of the gravity model theory, that is, dividing the actual value of bilateral trade per year by the annual bilateral trade estimates and defining as "over-trading" if the actual values are higher than the estimates, while "Under-trade" if less. According to the classification of trade potential values by Qingfeng Liu and Shushu Jiang (2002), a value greater than 1.2 indicates that the trade potential between bilateral trading partners is very small while ranging from 0.8 to 1.2 indicating the trade potential between trading partners Limited and with 
a pioneering, and less than 0.8 shows the trade potential between the trading partners is great that need to dig deep.

Table3 Trade Potential of China and Major Developed Countries in Europe

\begin{tabular}{|l|l|l|l|l|l|l|l|l|l|l|l|}
\hline $\begin{array}{l}\text { Country } \\
\text { And } \\
\text { Time }\end{array}$ & 2007 & 2008 & 2009 & 2010 & 2011 & 2012 & 2013 & 2014 & 2015 & 2016 & average \\
\hline England & 0.9823 & 0.9871 & 1.0002 & 0.9948 & 0.9935 & 0.9932 & 0.9945 & 0.9946 & 1.0015 & 1.0033 & 0.9945 \\
\hline Italy & 0.9882 & 0.9874 & 0.9902 & 0.9963 & 0.9931 & 0.9820 & 0.9789 & 0.9821 & 0.9938 & 0.9901 & 0.9882 \\
\hline Spain & 0.9982 & 0.9980 & 0.9902 & 0.9923 & 0.9897 & 0.9856 & 0.9817 & 0.9849 & 1.0001 & 0.9976 & 0.9918 \\
\hline Sweden & 0.9847 & 0.9829 & 1.0032 & 0.9861 & 0.9802 & 0.9766 & 0.9707 & 0.9692 & 0.9829 & 0.9750 & 0.9812 \\
\hline $\begin{array}{l}\text { Netherlan } \\
\text { ds }\end{array}$ & 1.0787 & 1.0678 & 1.0721 & 1.0719 & 1.0722 & 1.0725 & 1.0675 & 1.0671 & 1.0796 & 1.0763 & 1.0726 \\
\hline Finland & 1.0399 & 1.0252 & 1.0221 & 1.0147 & 1.0110 & 1.0117 & 0.9933 & 0.9849 & 0.9838 & 0.9744 & 1.0061 \\
\hline France & 0.9816 & 0.9769 & 0.9844 & 0.9829 & 0.9809 & 0.9798 & 0.9717 & 0.9752 & 0.9855 & 0.9788 & 0.9798 \\
\hline Germany & 1.0223 & 1.0210 & 1.0321 & 1.031 & 1.0287 & 1.0256 & 1.0184 & 1.0194 & 1.0264 & 1.0219 & 1.0247 \\
\hline Belgium & 1.0548 & 1.0474 & 1.0511 & 1.0484 & 1.0534 & 1.0459 & 1.0359 & 1.036 & 1.0427 & 1.0355 & 1.0451 \\
\hline Ireland & 1.026 & 1.0327 & 1.0404 & 1.0352 & 1.0328 & 1.0344 & 1.0225 & 1.0254 & 1.0222 & 1.0016 & 1.0273 \\
\hline
\end{tabular}

By comparing the estimated value of the total volume of import and export trade between China and the above countries through the random-effects model, the trade potential value between China and the trading partners was obtained from 2007 to 2016. As shown in the table, the trade potential between China and the trading partners in the past decade has been between 0.8-1.2. That is to say, the trade potential between China and European countries is not fully realized. From a time trend perspective, the trade potential values of various countries in the country started to increase and then decrease in 2013. In other words, since "the Belt and Road" Initiatives adopted by all countries in China and Europe in 2013, they have been striving to open the door to trade with each other and tap the potential of bilateral trade. With the continuous development of "the Belt and Road" initiative, the potential for trade has another tendency of declining. This may be due to the development of "the Belt and Road" initiative that has created new trade potentials and promoted the development of trade between China and the EU.

\section{Conclusions and Policy Recommendations}

\section{Complementary Development Based on own Advantages}

Earlier, through RCA, we have analyzed the competitive advantage of China's exports on the world in the past decade is mainly reflected in the labor-intensive products, while the natural resource endowments and the capital technical factor endowments are in bad position compared with the major developed countries in Europe. Therefore, we should base ourselves on our comparative advantages and consolidate the export of labor-intensive products, and meanwhile endeavor to add more technological added value in order to increase the competitiveness of China's export products in the world.

\section{Strengthen the Cooperation with all European Countries}

The European countries have experienced turmoil in recent years while the euro zone currency experienced a sharp devaluation and the United Kingdom leave the EU that made the European Union as the core of the European economy begin to decline. We need to truly open the door to Europe through "the Belt and Road" initiative and truly solve the technical barriers by boosting the infrastructure construction in the countries along the line, strengthening trade and cooperation with European countries. 


\section{Pave the Way for Political Factors to truly Bring European Countries into the B\&R Initiative}

Since 2013, 24 European countries have joined in the B\&R initiative, including Russia, Poland, the Czech Republic, Slovakia, Hungary, Slovenia, Croatia, Romania, Bulgaria, Serbia, Montenegro, the Republic of Macedonia, Bosnia and Herzegovina, Albania Estonia, Lithuania, Latvia, Turkey, Ukraine, Armenia, Moldova, Azerbaijan, Belarus and Georgia. Major European developed countries, such as Britain and France, have enjoyed the promotion brought by the B\&R initiative but have not really joined in it yet. We need to work hard to bring more European countries into the B\&R initiative through the radiation role of the countries along the line that have joined the B\&R initiative in order to truly achieve "peace and cooperation, openness and inclusiveness, mutual learning and mutual benefit".

\section{References}

[1] Guo-An WANG, Chang-Zi FAN, Study on the Complementarity between China and EU - An Empirical Analysis Based on Comparative Advantage Theory and Intra-industry Trade Theory, J. International Trade Issues. 3(2006) 61-66. (In Chinese)

[2] Chun-Rong YAN, Qiu-Ju ZHANG, China and the EU trade complementarities and competitiveness of empirical research, J. Financial Research. 21 (2010) 40-45. (In Chinese)

[3] Chun-Rong YAN, Empirical Analysis of the Comparative Advantage of China-EU Trade, J. Economic Survey. 1(2011) 42-47. (In Chinese)

[4] Jin-Yan SUN, An empirical study of the bilateral trade complementarities and trade potential between China and Australia based on the gravity model, J. Asia Pacific Economy. 6(2015) 85-90. (In Chinese)

[5] Huai-Yu TAN, An Empirical Analysis of the Potentialities of China-EU Trade Development Based on the Trade Gravity Model, J. News Economy. 39 (2017) 47-52. (In Chinese)

[6] Yan-Mei TIAN, The Impact of Sino-Korea Free Trade Area on the Goods Trade in Shandong Province: An Empirical Analysis Based on Gravity Model, J. Business Economics Research. 22(2017) 138-141. (In Chinese)

[7] Kojima K, International trade among developed countries, J. Hitotsubashi Journal of Economics. 5(1964) 16-36.

[8] Balassa B, Trade liberalization and revealed com-parative advantage, J. Manchester School of Economic and Social Studies. 33(1965) 99-124.

[9] Glick R, Rose A M, Contagion and trade: Why are currency crises regional, J. Journal of International Money and Finance. 18(1999) 99-123.

[10] Morrow, Ricardian-Heckscher-Ohlin Comparative Advantage: Theory and Evidence, P. Journal of International Economics. 82(2010) 137-151. 